\title{
Methylmercury in marine fish from Malaysian waters and its relationship to total mercury content.
}

\begin{abstract}
The study evaluated methylmercury concentrations, the methylmercury to total mercury ratio $(\% \mathrm{MeHg})$ and their correlations in ten fish species from different trophic levels. Methylmercury levels in fish studied were in the range of 0.007 to $0.914 \mu \mathrm{g} \mathrm{g}-1$ wet wt. Muscle tissue of predatory fish contained significantly $(\mathrm{p}<0.05)$ higher content of methylmercury than non-predatory fish. The methylmercury to total mercury ratio ranged from $49.1 \%$ to $87.5 \%$, with the highest ratio in predatory fish. This ratio was always higher in muscle tissue compared to the liver tissues, indicating tissue-specific binding and accumulation of methylmercury in the muscle. All the fish species showed strong positive correlation between methylmercury and total mercury levels ( $2>0.86$ ). Except for long tail tuna and short-bodied mackerel, all fish species showed lower methylmercury levels and estimated weekly intake as compared to the maximum values established by US FDA (of 0.5 $\mu \mathrm{g} \mathrm{g}-1)$ and by FAO/WHO (1.5 $\mu \mathrm{g} \mathrm{kg}-1$ bodyweight), respectively. This study showed that the percentage of methylmercury is rather high in fish and fish represents the major source of this toxic mercury form to the local population.
\end{abstract}

Keyword: Methylmercury; Total mercury; Correlation; Marine fish; Exposure assessment. 